\title{
Association of socioeconomic variables with bullying, being a victim, life dissatisfaction, and poor self-rated health in Iranian children and adolescents: the CASPIAN-V study
}

Mostafa Qorbani

Alborz University of Medical Sciences

Mostafa Amini Rarani

Isfahan University of Medical Sciences

Amir Kasaeian

Tehran University of Medical Sciences

Shirin Djalalinia

ministry of health and medical education

Kourosh Nouri

Alborz University of Medical Sciences

Hadith Rastad

Alborz University of Medical Sciences

Mohammad Esmaeil Motlagh

Ahvaz Jondishapour University of Medical Sciences

Ramin Heshmat ( $\triangle$ mqorbani1379@gmail.com )

Roya Kelishadi

Isfahan University of Medical Sciences

Research article

Keywords: Adolescents, Bully,Victim, Children, Life dissatisfaction, Self-rated health

Posted Date: March 3rd, 2020

DOI: https://doi.org/10.21203/rs.3.rs-15816/v1

License: (c) (i) This work is licensed under a Creative Commons Attribution 4.0 International License. Read Full License 


\section{Abstract}

Background Bullying, being a victim of violent behaviors, life satisfaction (LS) and self-rated health (SRH) in children and adolescents, all have consistently been recognized as vital factors in school performance and future individual life. In this study we examined the association of some socioeconomic variables with bullying, being a victim, life dissatisfaction (LDS), and poor self-rated health (SRH) in Iranian children and adolescents.

Methods This cross-sectional data secondary study was a part of the fifth Childhood and Adolescence Surveillance and Prevention of Adult Non-communicable disease (CASPIAN-V) in 2015. A total of 14,400 students 7-18 years and their parents living in 30 provinces in Iran were studied. A validated questionnaire of the World Health Organization on Global School-based Health Survey (WHO-GSHS) was used to measure the outcomes and socioeconomic variables. Family's socioeconomic status (SES) was determined using principle component analysis (PCA). The crude and adjusted odds ratios $(95 \% \mathrm{Cl})$ were estimated using multiple logistic regression for each outcome.

Results A total of 14,274 students ( $50.6 \%$ boys, $49.4 \%$ girls)) completed the study. The prevalence of bullying, being a victim, LDS, and poor SRH was $35.6 \%, 21.4 \%, 21.1 \%$, and $19.0 \%$ respectively. In multiple-logistic regression analysis, mother illiteracy (versus college degree) increased the odds of bullying (Adj.OR $(95 \% \mathrm{Cl})$, 1.77(1.45-2.16), being a victim (Adj.OR (95\%Cl),1.58(1.26-1.98), LDS (Adj.OR (95\%Cl),1.64 (1.30-2.08)) and PoorSRH (Adj.OR (95\% Cl), 1.60(1.25-2.04). Students with illiterate father(Adj.OR $(95 \% \mathrm{Cl}), 1.28(1.03-1.61)$ or unemployed father (Adj.OR (95\%Cl),1.58(1.29-1.81)) had a higher odds of Poor-SRH. Moreover, family size > 4 members (Adj.OR (95\% Cl), 1.14(1.03-1.25), and low-SES (Adj.OR (95\% Cl), 1.35(1.15-1.56), and illiteracy of mother (Adj.OR (95\% Cl), 1.64(1.30-2.08) had direct association with LDS. Living in a two- parent family decreased the odds of LDS (Adj.OR $(95 \% \mathrm{Cl}), 0.76(0.61-0.95)$.

Conclusions Some socioeconomic variables can be proposed as the main attribution of bullying and being a victim, LDS, and Poor-SRH in children and adolescents.

\section{Background}

Among many topics that are important to any discussion of the interface between early life experience and total health, bullying at the school setting, life dissatisfaction (LS) and self-rated health (SRH) are increasingly documented as predictors to instant and long-run health outcomes [1-3].

Despite the fact that bullying, formerly regarded as a normal part of children's growing up [4], previous studies have explained a negative association between bullying and health outcomes $[5,6]$. A study in the 21 European rich countries composing the Organization for Economic Co-operation and Development (OECD) verified that 1 out of 3 of children have been bullied at least once during the last two months [7]. In Iran, a study in a sample of middle school students revealed that $79.6 \%$ of students are involved in bullying and $81 \%$ are suffered bullying [8].

Life satisfaction (LS) is referred to the subjectively perceived quality of life according to the personal preferences of several life domains and the satisfaction in these domains [9]. Life dissatisfaction (LDS) has been closely related to a range of negative personal, behavioral, psychological and social outcomes $[10,11]$. The majority of 
previous researches on LS (or LDS) has been conducted primarily with adult participants [10], and relatively limited studies have investigated in childhood and adolescence [12].

Self-rated health (SRH), as a single-item health predictor [1], is to ask about an individual's perception of their own overall health status [13]. Because of SRH consequences in adult life, exploring the SRH and its associated factors in early life may be of particular interest in health researches. Previous studies suggest that conceptualizing health [14] and establishing healthy behaviors $[15,16]$ begin from early childhood and adolescence. Further, studies indicate that it can be regarded as the predictor of mortality [17], morbidity [18] and use of health care services $[16,19]$.

Given that bullying, being a victim, LDS, and SRH have consistently been recognized as vital factors associated with positive growth, good health and well-being in adulthood period, understanding of socioeconomic variables attributed to them in childhood and adolescence is important. Limited information is available on the socioeconomic determinants of childhood and adolescence self-rated health [20,21], bullying, being a victim of violent behavior and LDS at a school settings, especially in low and middle-income countries. Furthermore, as childhood and adolescents groups are often overlooked in health policy [21], this study allows policymakers to broaden their focus and to better develop early life-related health policies. Our objectives were to examine some socioeconomic variables on 1) bulling, 2) being victim, 3) LDS and 4) Poor SRH among Iranian children and adolescents.

\section{Methods}

This is the multicentric cross-sectional fifth survey of a surveillance program entitled "Childhood and Adolescence Surveillance and Prevent 1 on of Adult Non- communicable disease" (CASPIAN V) study (2015). Detailed methodology and executive procedures described previously [22], here we point to essential subjects.

\section{Study participants}

Using a multistage, stratified cluster sampling method, the study participants consisted of children and adolescents aged 7-18 years from primary and secondary schools of urban and rural areas of the country. We designed the proportional to size sampling method with equal sex ratio. Aim to that, within each province; the student's place of residence (urban or rural) and level of education (primary and secondary) applied.

\section{Questioning procedures}

Based on the World Health Organization- Global School-based student Health Survey (WHO-GSHS), two specific sets of questionnaires were developed for students and their parents. The student's questionnaire was obtained from the WHO-GSHS that was translated into Persian. The validity and reliability of questionnaires have been confirmed previously. After explaining the aims of the study and executive procedure, we obtained written informed consent from the parents and oral agreement from the students.

\section{Definitions}

- Bullying: 
Bullying assessed through questioning about: "During the past 3 months, how often did you bully at school?". The possible choices defined as: "None" (considered as no), "One to two times" (considered as yes), "Two to three times" (considered as yes) and "Four times or more" (considered as yes) [23, 24].

\section{- Being Victim}

According to the Global School-based Student Health Survey (GSHS) questionnaire of psychiatric distress and violent behaviors, victim detected by questioning on "During the past 3 months, how often did you get bullied at school?" The response choices categorized as; "None” (considered as no), "One to two times” (considered as yes), "Two to three times" (considered as yes) and "Four times or more" (considered as yes) [23, 24].

\section{- Socioeconomic status}

The methods and variables of calculating the family SES selected based on the categories approved in the Progress International Reading Literacy Study (PIRLS) for Iran[25]. The SES data was extracted from the parents' questionnaire. The participants' SES was determined based on the results of principle component analysis (PCA) variables of parents' education, occupation, possessing a private car, their school type (public/private), home type (private/rented) and having a personal computer at home. The SES score was a weighted average of the SES variables that were summarized under one main component of SES score. A lower score corresponded to a lower SES. The calculated score was categorized into tertiles to define SES levels. The first tertile was considered 'low', and the second and third ones as 'middle' and 'high' SES, respectively[24].

\section{- Life dissatisfaction (LS)}

To evaluating the Life dissatisfaction (LDS), the participants were asked to express their degree of life satisfaction according to a tenth-point scale from $1=$ very dissatisfied to $10=$ very satisfied. Based on the results, below 6 scores considered as Life dissatisfaction (LDS) [26, 27].

\section{- Self -rated health (SRH)}

Self -rated health (SRH) of students were assessed through questioning about "How would you describe your general state of health?" The response choices categorized as; "perfect," "good," "moderate," and "bad” [26, 27]. We summarized the responses as either 'not poor' (perfect or good) or 'poor' (moderate or bad) SRH

\section{Statistical analysis}

Quantitative variables are expressed as mean and standard deviation (SD) and qualitative variables as number (\%). Chi-square test was used to compare the self -rated health, life satisfaction, and violent behaviors across the socioeconomic status variables. The association of socioeconomic status variables and violent behaviors, self rated health, life satisfaction, evaluated using different logistic regression models. Model I was a crude model (without adjustment); in model II, the association was adjusted for all socioeconomic status variables and age, simultaneously. All statistical analyses were conducted based on survey data analysis methods. Data were analyzed using the STATA package V.11.0 (Stata Statistical Software: Release 11. College Station, Texas, USA: StataCorp LP Package) and a p-value $<0.05$ was considered significant. 


\section{Ethical concerns}

Study protocols were approved by ethical committees and other relevant national regulatory organizations. The Research and Ethics Council of Isfahan University of Medical Sciences approved the study (Project Number: 194049). After a complete explanation of the study objectives and protocols, written informed consent and verbal consent were obtained from the parents and students, respectively.

\section{Results}

A total of 14,274 students (50.6\% boys, $49.4 \%$ girls) and one of their parents (out of 14,400, participation rate) completed the survey (participation rate: 99\%). Table 1 shows the demographic and family characteristics of students, totally and by sex group.

The mean \pm SD age of students was $12.3 \pm 3.2$ years, with no significant difference between girls and boys. In girls compared to boys, a higher percentage of mothers had college degree $(14.7 \%$ vs. $12.8 \%, p=0.009)$ and were employed $(13.7 \%$ vs. $11.8 \%, p<0.001)$. There were any significant differences in other demographic and family characteristics between boys and girls.

Overall, $35.6 \%$ (95\% Cl: 34.9 - 36.4\%) of students reported that they bullied , and $21.4 \%$ (95\% Cl: $20.7-22.0 \%)$ of them was a victim during the past 3 months. $21.1 \%$ (95\% Cl: $20.4-21.8)$ of our participants were dissatisfied in life and $19.0 \%$ (95\% Cl:18.4-19.7\%) of them rated their health as poor. Table 2 presents the frequency of bullying, being victim, life dissatisfaction and poor health status according to sex and socioeconomic variables.

All our outcomes including bullying, being victim, life dissatisfaction, and poor Self-rated health were more frequent among individuals with socioeconomic status low (versus higher levels of SES), and those who their mother were illiterate (versus other levels of education). (all $p<0.05$ ).

A higher percentage of individuals with family size more than four members (versus family size $\leq 4$ ), singleparent family (versus two parents), and unemployed father (versus employed) were dissatisfied in their life. (all p-value < 0.05)

Poor health status was less reported among those who their father had a college degree (versus less than college) or were employed (versus unemployed). (both p-value <0.05)

A lower percentage of individuals with single parents (versus two parents) and academic education level of a father ( versus less than a college degree) described being a victim during the past 3 months . In addition, a lower percentage of students who their mother were employed (versus unemployed) or their father had a college degree (versus less than college degree), reported bulling during the past 3 months. (All p-value $<0.05$ )

In the adjusted model of logistic regression analysis that all socioeconomic status variables and age were simultaneously in the model, higher odds of bullying was observed among students who lived in low SES (Adj.OR (95\%Cl): 1.21 (1.06-1.38)), two-parent family (Adj.OR (95\%Cl): 1.39 (1.13-1.71)), and those who their mothers had education level $\leq$ diploma (Adj.OR (95\%Cl): 1.46 (1.25-1.70)) or illiterate (Adj.OR (95\%Cl): 1.77 $(1.45-2.16))$. Also, odds of being victim of violence was higher among students with mother's education level $\leq$ diploma (Adj.OR, (95\%Cl): 1.20 (1.01-1.43) ) or illiterate (Adj.OR (95\%Cl): 1.58 (1.26-1.98)), father education level 
$\leq$ diploma (Adj.OR (95\% Cl): 1.19(1.03-1.38)), , but it was 18\% lower among those who their mothers were unemployed (Adj.OR (95\%Cl):0.82 (0.71-0.95)). (Table 3).

As presented at Table 4, students of illiterate mother (Adj.OR (95\%Cl):1.64 (1.30-2.08)), low SES family (Adj.OR $(95 \% \mathrm{Cl}): 1.35$ (1.15-1.56)), and family size > 4 (Adj.OR (95\%Cl):1.14 (1.03-1.25)), had a higher odds of LDS. However, living in a two-parent family indicated an indirect association with life dissatisfaction (Adj.OR $(95 \% \mathrm{Cl})$ : $0.76(0.61-0.95))$,

Besides, both maternal and paternal education level less than college ( $\leq$ diploma \& illiterate), and the unemployment of father, all were associated with higher odds of poor health status. (All p-value $<0.05$ )

There was not a significant association between other socioeconomic variables with the assessed outcomes. The crude and adjusted odds ratios were generally similar (as in

Table 3\&4).

\section{Discussion}

In this study, using a nationally representative dataset from CASPIAN V, we focused on socioeconomic variables of bullying, being a victim, life dissatisfaction (LDS) and poor SRH among students aged 7 to 18 years in Iran. We mainly tried to clarify attributed socioeconomic variables of the mentioned outcome variables. To our knowledge, this is the first attempt to declare socioeconomic attributions related to bullying, being a victim, LDS and poor SRH in the early life simultaneously in this country. It is important since the influencing variables in early life pave the way for health status and well-being later in life [28]. The findings imply that among socioeconomic variables, mother's illiteracy increased the odds of bullying, being a victim, LDS and poor SRH among students. Further, father's illiteracy and low level of education , and father's unemployment increase the odds of poor SRH. Moreover, family size $>4$, single parent and low-SES were associated with life dissatisfaction.

To our good knowledge, there is still no evidence on socioeconomic factors associated with bullying in Iran. However, our finding contributes to the existing literature suggesting the role of family characteristics including parental education as an important factor related to the risk of bullying [29-31]. We find that mother's illiteracy and low maternal education are risk factors for students to getting a bully and a victim. Our result is in keeping with previous findings that show low parental education level has been associated with increased risk of bullying [30, 32, 33]. Jansen et al., using longitudinal data from a subsample of the Tracking Adolescents' Individual Lives Survey (TRAILS) in Netherlands found that children from low educational level of the father and the mother (as a marker of low socioeconomic status of families) were more likely to get a bully, victim, or bully/victim [30]. In Germany, Von Marées and Petermann, using a cross-informant approach showed that low parental education levels significantly increased chance of being a bully/victim among primary school children [33]. Nordhagen et al., in a cross-sectional comparative study conducted in the five Nordic countries, showed that children of parents with low education seemed to be bullied more often than counterparts with high education [32]. Nevertheless, some other studies revealed no statistically significant association between parental education level and bullying among children and adolescents [6,31]. About the negative effects of low parental education on bullying one can assume that parent's low educational level as so-called risk marker [33], can raise risk factors such as authoritarian parenting style, family stress, parental conflicts, poor communication with parents, lack involvement and warmth in family [34] and household material deprivation [31] which are related to 
bullying. It was also implying that parents with low education less involved with school activities and policies that has been a risk factor for getting a bully or a victim [35].

Findings related to socioeconomic variables and LDS are consistent with those of other studies [2, 10,36-38]. Adolescent LDS is related to a variety of early life experiences in the family environment [39]. Out of these early experiences, as we found, family composition including family size (i.e. number of adults living in the home) is significantly related to LDS. From a review of literature, no studies were found in other countries that explored the association of family size with LDS. However, in Iran, Kelishadi et al., using information of 13,486 students aged 6-18 years found that LDS significantly higher in students with $>4$ family members [37]. It is suggested that crowded families may be related to the continuing struggle for achieving household financial resources and emotional supports, low rate of room per capita, limited share of foods and more conflicts between siblings and hence lead to a low level of life satisfaction (LS) among family members. We found that families with single parents increased likelihood of dissatisfying life between students. This finding is also consistent with previous studies that showed living with single parents had inverse relationship with LS [37, 40, 41]. In United States, Zulling et al., using statewide data from Youth Risk Behavior Survey (YRBS) indicated that both white males' and females' adolescents who reported living with two parents were significantly less likely to report LDS [41]. The mother's illiteracy was a risk factor of LDS in our study. A study among European American, African American, Chinese American, Mexican American, and Dominican American adolescents showed that LS was positively correlated with parental education [42]. Moreover, Crede et al. in a sample of German high school students reported that although fathers' education did not moderate the relationship between students' LS scores and academic achievement, mothers' education did [43]. Nevertheless, another study in USA reported that no statistical significance between mother's and father's level of education and LS [44]. The finding respect to family SES and LDS was consistent with different studies that show significant direct association between low SES and LDS $[36,45,46]$. In the study included a sample of 2823 Croatian high school students, authors concluded that adolescents' perception of their family's economic status had a modest positive correlation to LS [46]. Chappal et al. showed that students in the low SES group reported lower LS compared to middle/high SES students [45]. In Iran, Mirmoghtadaee et al. showed that compared to high family SES, low family SES increases the odds of low LS [26]. Kelishadi et al. also reported the same findings [37]. However, some studies examining the role of SES with respect to LS reported no difference disfavor of lower SES students [47, 48].

With regard to SLR students who belonging to illiterate mothers and fathers, fathers with a low level of education and unemployment were more likely to have poor SRH. It also was consistent with some other studies [1, 49, 50]. Goodman et al., recruiting 1179 adolescents from Princeton City School District demonstrated that lower parent education associated with fair-poor SRH [49]. Results from 22 European and North American countries showed that the most deprived students (i.e. students with a low level of parental education and occupation) had an odds ratio for self-rated poor health nearly three times higher than the least deprived students [50].

\section{Strengths And Limitations Of The Study}

The main strengths of the study lie on the quantity and quality of the data, collected in a large nationally representative sample size and designed and conducted according to standardized questionnaire of the World Health Organization on Global School-based Health Survey (WHO-GSHS). As data were drawn from a crosssectional study, causal interpretations should be made with caution. In fact, attribution of causality might be better discovered with prospective longitudinal research in the future studies. 


\section{Conclusions}

According to the findings, some socioeconomic variables can be proposed as the main attributions of bullying, being victim, LDS and poor-SRH in children and adolescents. Namely, parental education, father's occupation, family size as well as family's SES can be taken into account in anti-bullying initiatives and programs related to LS and SRH promotion.

\section{Declarations}

\section{Funding :}

This research received no specific grant from any funding agency, commercial or not-for-profit sectors

\section{Availability of data and materials:}

The data used in the current study are available from the corresponding authors on reasonable request.

\section{Ethics approval and consent to participate:}

The Research and Ethics Council of Isfahan University of Medical Sciences approved the study (Project Number: 194049).

\section{Consent for publication:}

Not applicable.

\section{Competing interests:}

All Authors have nothing to declare.

\section{Authors' contributions:}

R.H, M.Q, and R.K contributed to the idea and work plan. R.K and ME.M coordinated the data collection. A.K and SH.D carried out the analysis of the data, H.R, M.Q, K.N, and M.AR drafted and revised the manuscript incorporating the comments from the co-authors through an iterative process. All authors read and approved the final manuscript.

\section{Acknowledgment}

There was no external funding for this study. The authors are appreciative of the large team working on this nationwide project and the participants. The authors' special hanks also go to Emam Ali Hospital, Clinical Research Development Unit (Alborz University of Medical Sciences)

\section{References}

1. Breidablik, H.-J., E. Meland, and S. Lydersen, Self-rated health in adolescence: a multifactorial composite. Scandinavian Journal of Public Health, 2008. 36(1): p. 12-20. 
2. Gilman, R. and S. Huebner, A review of life satisfaction research with children and adolescents. School Psychology Quarterly, 2003. 18(2): p. 192.

3. Sigurdson, J., J. Wallander, and A. Sund, Is involvement in school bullying associated with general health and psychosocial adjustment outcomes in adulthood? Child abuse \& neglect, 2014. 38(10): p. 1607-1617.

4. Olweus, D., Bullying at school, in Aggressive behavior. 1994, Springer. p. 97-130.

5. Arseneault, L., Annual Research Review: The persistent and pervasive impact of being bullied in childhood and adolescence: implications for policy and practice. Journal of child psychology and psychiatry, 2018. 59(4): p. 405-421.

6. Sourander, A., et al., Persistence of bullying from childhood to adolescence-a longitudinal 8-year follow-up study. Child abuse \& neglect, 2000. 24(7): p. 873-881.

7. Unicef, A Comprehensive Assessment of the Lives and Well Being of Children and Adolescents in the Economically Advanced Nations. Florence, Italy: UNICEF Innocenti Center Card, 2007. 7.

8. Khezri, H., et al., Bullying and victimization: Prevalence and gender differences in a sample of Iranian middle school students. Journal of Educational and Management Studies, 2013. 3(3): p. 224-229.

9. Henrich, G. and P. Herschbach, Questions on Life Satisfaction (FLZM): A short questionnaire for assessing subjective quality of life. European Journal of Psychological Assessment, 2000. 16(3): p. 150.

10. Oberle, E., K.A. Schonert-Reichl, and B.D. Zumbo, Life satisfaction in early adolescence: Personal, neighborhood, school, family, and peer influences. Journal of youth and adolescence, 2011. 40(7): p. 889901.

11. Suldo, S.M. and E.S. Huebner, Is extremely high life satisfaction during adolescence advantageous? Social indicators research, 2006. 78(2): p. 179-203.

12. Gadermann, A.M., K.A. Schonert-Reichl, and B.D. Zumbo, Investigating validity evidence of the satisfaction with life scale adapted for children. Social Indicators Research, 2010. 96(2): p. 229-247.

13. Jørgensen, P., et al., Diagnostic labelling influences self-rated health. A prospective cohort study: the HUNT study, Norway. Family practice, 2015. 32(5): p. 492-499.

14. Breidablik, H.-J., E. Meland, and S. Lydersen, Self-rated health during adolescence: stability and predictors of change (Young-HUNT study, Norway). The European Journal of Public Health, 2008. 19(1): p. 73-78.

15. Marmot, M., et al., Closing the gap in a generation: health equity through action on the social determinants of health. The lancet, 2008. 372(9650): p. 1661-1669.

16. Vingilis, E.R., T.J. Wade, and J.S. Seeley, Predictors of adolescent self-rated health: analysis of the National Population Health Survey. Canadian Journal of Public Health/Revue Canadienne de Sante'e Publique, 2002: p. 193-197.

17. Jylhä, M., What is self-rated health and why does it predict mortality? Towards a unified conceptual model. Social science \& medicine, 2009. 69(3): p. 307-316.

18. Idler, E.L. and Y. Benyamini, Self-rated health and mortality: a review of twenty-seven community studies. Journal of health and social behavior, 1997: p. 21-37.

19. Tamayo-Fonseca, N., et al., Self-rated health and hospital services use in the Spanish National Health System: a longitudinal study. BMC health services research, 2015. 15(1): p. 492.

20. Boardman, J.D., Self-rated health among US adolescents. Journal of Adolescent Health, 2006. 38(4): p. 401408. 
21. Viner, R.M., et al., Adolescence and the social determinants of health. The lancet, 2012. 379(9826): p. 16411652.

22. Motlagh, M.E., et al., Methodology and early findings of the fifth survey of childhood and adolescence surveillance and prevention of adult noncommunicable disease: the CASPIAN-V Study. International journal of preventive medicine, 2017. 8.

23. Kelishadi, R., et al., Joint Association of Active and Passive Smoking with Psychiatric Distress and Violence Behaviors in a Representative Sample of Iranian Children and Adolescents: the CASPIAN-IV Study. International journal of behavioral medicine, 2015. 22(5): p. 652.

24. Heshmat, R., et al., Association of socioeconomic status with psychiatric problems and violent behaviours in a nationally representative sample of Iranian children and adolescents: the CASPIAN-IV study. BMJ Open, 2016. 6(8).

25. Ogle, L.T., et al., International Comparisons in Fourth-Grade Reading Literacy: Findings from the Progress in International Reading Literacy Study (PIRLS) of 2001. 2003.

26. Mirmoghtadaee, P., et al., The association of socioeconomic status of family and living region with selfrated health and life satisfaction in children and adolescents: The CASPIAN-IV study. Medical journal of the Islamic Republic of Iran, 2016. 30: p. 423.

27. Kelishadi, R., et al., Self-Rated health and life satisfaction in Iranian children and adolescents at the national and provincial level: the CASPIAN-IV study. Iranian Red Crescent Medical Journal, 2016. 18(12).

28. Compton, M.T. and R.S. Shim, The social determinants of mental health. Focus, 2015. 13(4): p. 419-425.

29. Beran, T.N. and C. Violato, A model of childhood perceived peer harassment: Analyses of the Canadian national longitudinal survey of children and youth data. The Journal of Psychology, 2004. 138(2): p. 129148.

30. Jansen, D.E., et al., Early risk factors for being a bully, victim, or bully/victim in late elementary and early secondary education. The longitudinal TRAILS study. BMC public health, 2011. 11(1): p. 440.

31. Wolke, D. and A.J. Skew, Family factors, bullying victimisation and wellbeing in adolescents. Longitudinal and Life Course Studies, 2011. 3(1): p. 101-119.

32. Nordhagen, R., et al., Parental reported bullying among nordic children: a population-based study. Child: care, health and development, 2005. 31(6): p. 693-701.

33. Von Marées, N. and F. Petermann, Bullying in German primary schools: Gender differences, age trends and influence of parents' migration and educational backgrounds. School Psychology International, 2010. 31(2): p. 178-198.

34. Bowes, L., et al., School, neighborhood, and family factors are associated with children's bullying involvement: A nationally representative longitudinal study. Journal of the American Academy of Child \& Adolescent Psychiatry, 2009. 48(5): p. 545-553.

35. Erginoz, E., et al., The role of parental, school, and peer factors in adolescent bullying involvement: Results from the Turkish HBSC 2005/2006 study. Asia Pacific Journal of Public Health, 2015. 27(2): p. NP1591NP1603.

36. Chen, W., et al., Socioeconomic status and life satisfaction in Chinese adolescents: Analysis of self-esteem as a mediator and optimism as a moderator. Personality and Individual Differences, 2016. 95: p. 105-109. 
37. Kelishadi, R., et al., Determinants of life satisfaction in Iranian children and adolescents: the CASPIAN-IV study. Child and Adolescent Mental Health, 2018. 23(3): p. 228-234.

38. Shek, D.T. and T.T. Liu, Life satisfaction in junior secondary school students in Hong Kong: A 3-year longitudinal study. Social Indicators Research, 2014. 117(3): p. 777-794.

39. Ash, C. and E.S. Huebner, Environmental events and life satisfaction reports of adolescents: A test of cognitive mediation. School Psychology International, 2001. 22(3): p. 320-336.

40. King, A.L.D., et al., An ecological view of school satisfaction in adolescence: Linkages between social support and behavior problems. Applied Research in Quality of Life, 2006. 1(3-4): p. 279-295.

41. Zullig, K.J., et al., Associations among family structure, demographics, and adolescent perceived life satisfaction. Journal of child and Family studies, 2005. 14(2): p. 195-206.

42. Bradley, R. and R. Corwyn, Life satisfaction among european american, african american, chinese american, mexican american, and dominican american adolescents. International Journal of Behavioral Development, 2004. 28(5): p. 385-400.

43. Crede, J., et al., Adolescents' academic achievement and life satisfaction: the role of parents' education. Frontiers in psychology, 2015. 6: p. 52.

44. Schlechter, M. and A. Milevsky, Parental level of education: associations with psychological well-being, academic achievement and reasons for pursuing higher education in adolescence. Educational Psychology, 2010. 30(1): p. 1-10.

45. Chappel, A.M., S.M. Suldo, and J.A. Ogg, Associations between adolescents' family stressors and life satisfaction. Journal of child and family Studies, 2014. 23(1): p. 76-84.

46. Raboteg-Šarić, Z., A. Brajša-Žganec, and M. Šakić, Life satisfaction in adolescents: The effects of perceived family economic status, self-esteem and quality of family and peer relationships. Društvena istraživanja: časopis za opća društvena pitanja, 2009. 18(3 (101)): p. 547-564.

47. Elmore, G.M. and E.S. Huebner, Adolescents' satisfaction with school experiences: Relationships with demographics, attachment relationships, and school engagement behavior. Psychology in the Schools, 2010. 47(6): p. 525-537.

48. Konu, A.I., T.P. Lintonen, and M.K. Rimpelä, Factors associated with schoolchildren's general subjective wellbeing. Health education research, 2002. 17(2): p. 155-165.

49. Goodman, E., et al., Perceived socioeconomic status: a new type of identity that influences adolescents' selfrated health. Journal of Adolescent Health, 2007. 41(5): p. 479-487.

50. Torsheim, T., et al., Material deprivation and self-rated health: a multilevel study of adolescents from 22 European and North American countries. Social science \& medicine, 2004. 59(1): p. 1-12.

\section{Tables}

Table 1: Socioeconomic characteristics and psychiatric distress according to sex: the CASPIAN-V study 


\begin{tabular}{|c|c|c|c|c|c|c|}
\hline \multirow[t]{2}{*}{ Variable } & & Girl & Boy & Total & & p-Value \\
\hline & & n (\%) & n (\%) & n (\%) & n (\%) & \\
\hline \multirow[t]{2}{*}{ Living area } & Urban & $5044(71.6)$ & $5150(71.3)$ & $10194(71.4)$ & $12(0.1)$ & 0.657 \\
\hline & Rural & $2002(28.4)$ & 2078 (28.7) & $4080(28.6)$ & & \\
\hline \multirow[t]{2}{*}{ Family size } & $\leq 4$ & $3291(47.4)$ & $3444(48.3)$ & 6735 (47.9) & $220(1.5)$ & 0.310 \\
\hline & $>4$ & 3645 (52.6) & 3686 (51.7) & $7331(52.1)$ & & \\
\hline \multirow[t]{3}{*}{ Maternal education level } & College degree & 776 ( 11.1$)$ & $747(10.4)$ & $1523(10.8)$ & $126(0.9)$ & 0.201 \\
\hline & Diploma and less & $5012(71.7)$ & 5125 (71.5) & 10137 (71.6) & & \\
\hline & Illiterate & $1202(17.2)$ & $1298(18.1)$ & $2500(17.7)$ & & \\
\hline \multirow[t]{3}{*}{ Paternal education level } & College degree & 997 (14.7) & 895 (12.8) & 1892 (13.7) & $508(3.6)$ & 0.006 \\
\hline & Diploma and less & 4941 (72.7) & $5211(74.6)$ & $10152(73.7)$ & & \\
\hline & Illiterate & 858 (12.6) & 876 (12.5) & $1734(12.6)$ & & \\
\hline \multirow[t]{2}{*}{ Maternal occupation status } & employed & 962 (13.7) & $850(11.8)$ & 1812 ( 12.7$)$ & $59(0.4)$ & 0.001 \\
\hline & unemployed & $6063(86.3)$ & $6352(88.2)$ & 12415 (87.3) & & \\
\hline \multirow[t]{2}{*}{ Paternal occupation status } & employed & $6382(91.3)$ & $6550(91.2)$ & $12932(91.2)$ & $108(0.8)$ & 0.833 \\
\hline & unemployed & $611(8.7)$ & $635(8.8)$ & $1246(8.8)$ & & \\
\hline \multirow[t]{2}{*}{ Family composition } & Two parents & $6586(94.1)$ & $6754(94.1)$ & $13340(94.1)$ & $110(0.8)$ & 0.986 \\
\hline & Single parent & $413(5.9)$ & $423(5.9)$ & $836(5.9)$ & & \\
\hline \multirow[t]{3}{*}{ Family socioeconomic status (SES) } & Low & $2234(33.3)$ & 2325 (33.6) & 4559 (33.5) & $660(4.6)$ & 0.077 \\
\hline & Mid & $2172(32.4)$ & $2343(33.8)$ & $4515(33.1)$ & & \\
\hline & High & 2297 (34.3) & $2255(32.6)$ & $4552(33.4)$ & & \\
\hline
\end{tabular}

Table 2. Frequency of bullying, being victim, life dissatisfaction, and poor Self-rated health according to sex and socioeconomic variables: the CASPIAN-V study 


\begin{tabular}{|c|c|c|c|c|c|c|c|c|c|}
\hline \multicolumn{2}{|l|}{ Variable } & \multirow{2}{*}{$\begin{array}{l}\text { Bullying } \\
\text { n (\%) }\end{array}$} & \multirow{2}{*}{$\begin{array}{l}\text { p- } \\
\text { Value }\end{array}$} & \multirow{2}{*}{$\begin{array}{l}\text { Being } \\
\text { a } \\
\text { Victim } \\
\text { n (\%) }\end{array}$} & \multirow{2}{*}{$\begin{array}{l}\text { p- } \\
\text { Value }\end{array}$} & \multirow{2}{*}{$\begin{array}{l}\text { Life } \\
\text { dissatisfaction } \\
\mathrm{n}(\%)\end{array}$} & \multirow{2}{*}{$\begin{array}{l}\mathrm{p}- \\
\text { Value }\end{array}$} & \multirow{2}{*}{$\begin{array}{l}\text { Poor Self- } \\
\text { rated } \\
\text { health, } \mathrm{n} \\
(\%)\end{array}$} & \multirow{2}{*}{$\begin{array}{l}\text { p- } \\
\text { Value }\end{array}$} \\
\hline & & & & & & & & & \\
\hline \multirow[t]{2}{*}{ Sex } & Boy & $\begin{array}{l}2583 \\
(35.9)\end{array}$ & 0.486 & $\begin{array}{l}1573 \\
(21.8)\end{array}$ & 0.137 & $1508(21.0)$ & 0.738 & $\begin{array}{l}1345 \\
(18.8)\end{array}$ & 0.538 \\
\hline & Girl & $\begin{array}{l}2477 \\
(35.3)\end{array}$ & & $\begin{array}{l}1460 \\
(20.8)\end{array}$ & & $1488(21.2)$ & & $\begin{array}{l}1341 \\
(19.2)\end{array}$ & \\
\hline \multirow[t]{2}{*}{ Living area } & Urban & $\begin{array}{l}3562 \\
(35.1)\end{array}$ & 0.061 & $\begin{array}{l}2128 \\
(21.0)\end{array}$ & 0.106 & 2110 (20.8) & 0.213 & $\begin{array}{l}1929 \\
(19.1)\end{array}$ & 0.589 \\
\hline & Rural & $\begin{array}{l}1498 \\
(36.8)\end{array}$ & & $\begin{array}{l}905 \\
(22.2)\end{array}$ & & $886(21.8)$ & & 757 (18.8) & \\
\hline \multirow[t]{2}{*}{ Family size } & $\leq 4$ & $\begin{array}{l}2382 \\
(35.5)\end{array}$ & 0.915 & $\begin{array}{l}1421 \\
(21.1)\end{array}$ & 0.505 & 1270 (18.9) & $<0.001$ & $\begin{array}{l}1279 \\
(19.1)\end{array}$ & 0.955 \\
\hline & $>4$ & $\begin{array}{l}2579 \\
(35.4)\end{array}$ & & $\begin{array}{l}1575 \\
(21.6)\end{array}$ & & $1693(23.2)$ & & $\begin{array}{l}1380 \\
(19.1)\end{array}$ & \\
\hline \multirow[t]{3}{*}{$\begin{array}{l}\text { Maternal } \\
\text { education level }\end{array}$} & $\begin{array}{l}\text { College } \\
\text { degree }\end{array}$ & $\begin{array}{l}445 \\
(29.4)\end{array}$ & $<0.001$ & $\begin{array}{l}304 \\
(20.1)\end{array}$ & $<0.001$ & 293 (19.4) & $<0.001$ & 246 (16.3) & $<0.001$ \\
\hline & $\begin{array}{l}\text { Diploma and } \\
\text { less }\end{array}$ & $\begin{array}{l}3591 \\
(35.6)\end{array}$ & & $\begin{array}{l}2090 \\
(20.7)\end{array}$ & & 1978 (19.6) & & $\begin{array}{l}1862 \\
(18.6)\end{array}$ & \\
\hline & illiterate & $\begin{array}{l}976 \\
(39.2)\end{array}$ & & $\begin{array}{l}621 \\
(24.9)\end{array}$ & & $680(27.3)$ & & $558(22.6)$ & \\
\hline \multirow[t]{3}{*}{$\begin{array}{l}\text { Paternal } \\
\text { education level }\end{array}$} & $\begin{array}{l}\text { College } \\
\text { degree }\end{array}$ & $\begin{array}{l}615 \\
(32.7)\end{array}$ & 0.010 & $\begin{array}{l}347 \\
(18.4)\end{array}$ & 0.001 & 365 (19.4) & 0.110 & $284(15.1)$ & $<0.001$ \\
\hline & $\begin{array}{l}\text { Diploma and } \\
\text { less }\end{array}$ & $\begin{array}{l}3645 \\
(36.1)\end{array}$ & & $\begin{array}{l}2243 \\
(22.2)\end{array}$ & & $2142(21.2)$ & & 1963(19.6) & \\
\hline & illiterate & $\begin{array}{l}591 \\
(34.2)\end{array}$ & & $\begin{array}{l}357 \\
(20.7)\end{array}$ & & $382(22.1)$ & & 354 (20.7) & \\
\hline \multirow{2}{*}{$\begin{array}{l}\text { Maternal } \\
\text { occupation } \\
\text { status }\end{array}$} & Employed & $\begin{array}{l}603 \\
(33.4)\end{array}$ & 0.036 & $\begin{array}{l}405 \\
(22.5)\end{array}$ & 0.223 & 373 (20.7) & 0.661 & 319 (17.8) & 0.138 \\
\hline & Unemployed & $\begin{array}{l}4443 \\
(36.0)\end{array}$ & & $\begin{array}{l}2620 \\
(21.2)\end{array}$ & & $2610(21.1)$ & & $\begin{array}{l}2360 \\
(19.2)\end{array}$ & \\
\hline \multirow{2}{*}{$\begin{array}{l}\text { Paternal } \\
\text { occupation } \\
\text { status }\end{array}$} & Employed & $\begin{array}{l}4573 \\
(35.5)\end{array}$ & 0.881 & $\begin{array}{l}2771 \\
(21.5)\end{array}$ & 0.151 & 2667 (20.7) & 0.011 & 199 (16.1) & 0.005 \\
\hline & Unemployed & $\begin{array}{l}444 \\
(35.7)\end{array}$ & & $\begin{array}{l}246 \\
(19.8)\end{array}$ & & 296 (23.8) & & $\begin{array}{l}2478 \\
(19.4)\end{array}$ & \\
\hline \multirow[t]{2}{*}{$\begin{array}{l}\text { Family } \\
\text { composition }\end{array}$} & Two parents & $\begin{array}{l}4739 \\
(35.7)\end{array}$ & 0.107 & $\begin{array}{l}2866 \\
(21.6)\end{array}$ & 0.007 & $2760(20.8)$ & .008 & $\begin{array}{l}2507 \\
(19.0)\end{array}$ & 0.579 \\
\hline & $\begin{array}{l}\text { Single } \\
\text { parent }\end{array}$ & $\begin{array}{l}274 \\
(32.9)\end{array}$ & & $\begin{array}{l}147 \\
(17.6)\end{array}$ & & $205(24.6)$ & & $162(19.8)$ & \\
\hline Family & low & 1723 & $<0.001$ & 1031 & 0.023 & $1136(25.0)$ & $<0.001$ & $910(20.3)$ & 0.036 \\
\hline
\end{tabular}

Page 13/18 
socioeconomic

status (SES)
(38.0)

1597

(35.6)

1508

(33.3)
(22.7)

925

(20.6)

939

(20.7)
860 (19.1)

845 (18.9)

846 (18.7)

819 (18.2)

Table 3: Associations of socioeconomic status variables with bullying and being victim,: the CASPIAN V study, logistic regression analysis

*In the adjusted model, all socioeconomic status variables and age are simultaneously in the model

Table 4: Associations of socioeconomic status variables with life dissatisfaction and Poor Self-rated health: the CASPIAN V study, logistic regression analysis 


\begin{tabular}{|c|c|c|c|c|c|c|c|c|c|}
\hline \multirow[t]{3}{*}{ Variable } & & \multicolumn{4}{|l|}{ Bullying } & \multicolumn{4}{|c|}{ Being a victim } \\
\hline & & \multicolumn{2}{|c|}{ Crude model } & \multicolumn{2}{|c|}{ Adjusted model* } & \multicolumn{2}{|c|}{ Crude model } & \multicolumn{2}{|c|}{ Adjusted model* } \\
\hline & & $\begin{array}{l}\text { OR }(95 \% \\
\mathrm{CI})\end{array}$ & $\begin{array}{l}\mathrm{P}- \\
\text { value }\end{array}$ & $\begin{array}{l}\text { OR }(95 \% \\
\mathrm{CI})\end{array}$ & $\begin{array}{l}\mathrm{P} \text { - } \\
\text { value }\end{array}$ & $\begin{array}{l}\text { OR }(95 \% \\
\text { CI) }\end{array}$ & $\begin{array}{l}\mathrm{P} \text { - } \\
\text { value }\end{array}$ & $\begin{array}{l}\text { OR }(95 \% \\
\text { CI) }\end{array}$ & $\begin{array}{l}\mathrm{P} \text { - } \\
\text { value }\end{array}$ \\
\hline \multirow[t]{2}{*}{ Sex } & Girl & Reference & ------- & Reference & ------- & Reference & ------- & Reference & ------- \\
\hline & Boy & $\begin{array}{l}1.02 \\
(0.95- \\
1.09)\end{array}$ & 0.486 & $\begin{array}{l}1.03 \\
(0.95- \\
1.10)\end{array}$ & 0.420 & $\begin{array}{l}1.06 \\
(0.98- \\
1.15)\end{array}$ & 0.137 & $\begin{array}{l}1.06 \\
(0.97- \\
1.15)\end{array}$ & 0.144 \\
\hline \multirow[t]{2}{*}{ Living area } & Urban & Reference & ------- & Reference & ------- & Reference & ------- & Reference & ------- \\
\hline & Rural & $\begin{array}{l}1.07 \\
(0.99- \\
1.15)\end{array}$ & 0.061 & $\begin{array}{l}1.07 \\
(0.99- \\
1.16)\end{array}$ & 0.073 & $\begin{array}{l}1.07 \\
(0.98- \\
1.17)\end{array}$ & 0.106 & $\begin{array}{l}1.03 \\
(0.94- \\
1.13)\end{array}$ & 0.489 \\
\hline \multirow[t]{2}{*}{ Family size } & $\leq 4$ & Reference & ------- & Reference & ------- & Reference & ------- & Reference & ------- \\
\hline & $>4$ & $\begin{array}{l}0.99 \\
(0.93- \\
1.06)\end{array}$ & 0.915 & $\begin{array}{l}0.95 \\
(0.84- \\
1.08)\end{array}$ & 0.06 & $\begin{array}{l}1.02 \\
(0.94- \\
1.11)\end{array}$ & 0.505 & $\begin{array}{l}0.95 \\
(0.86- \\
1.04)\end{array}$ & 0.278 \\
\hline \multirow{3}{*}{$\begin{array}{l}\text { Maternal } \\
\text { education } \\
\text { level }\end{array}$} & $\begin{array}{l}\text { College } \\
\text { degree }\end{array}$ & Reference & ------- & Reference & ------- & Reference & ------- & Reference & ------- \\
\hline & $\begin{array}{l}\text { Diploma and } \\
\text { less }\end{array}$ & $\begin{array}{l}1.32 \\
(1.18- \\
1.49)\end{array}$ & $<0.001$ & $\begin{array}{l}1.46 \\
(1.25- \\
1.70)\end{array}$ & $<0.001$ & $\begin{array}{l}1.04 \\
(0.91- \\
1.19)\end{array}$ & 0.557 & $\begin{array}{l}1.20 \\
(1.01- \\
1.43)\end{array}$ & 0.035 \\
\hline & illiterate & $\begin{array}{l}1.55 \\
(1.35- \\
1.77)\end{array}$ & $<0.001$ & $\begin{array}{l}1.77 \\
(1.45- \\
2.16)\end{array}$ & $<0.001$ & $\begin{array}{l}1.32 \\
(1.13- \\
1.54)\end{array}$ & $<0.001$ & $\begin{array}{l}1.58 \\
(1.26- \\
1.98)\end{array}$ & $<0.001$ \\
\hline \multirow{3}{*}{$\begin{array}{l}\text { Paternal } \\
\text { education } \\
\text { level }\end{array}$} & $\begin{array}{l}\text { College } \\
\text { degree }\end{array}$ & Reference & ------- & Reference & ------- & Reference & ------- & Reference & ------- \\
\hline & $\begin{array}{l}\text { Diploma and } \\
\text { less }\end{array}$ & $\begin{array}{l}1.16 \\
(1.04- \\
1.29)\end{array}$ & 0.005 & $\begin{array}{l}1.01(0.92- \\
1.1)\end{array}$ & 0.80 & $\begin{array}{l}1.26 \\
(1.11- \\
1.43)\end{array}$ & $<0.001$ & $\begin{array}{l}1.19(1.03- \\
1.38)\end{array}$ & 0.02 \\
\hline & illiterate & $\begin{array}{l}1.07 \\
(0.93- \\
1.23)\end{array}$ & 0.315 & $\begin{array}{l}1.05 \\
(0.94- \\
1.24)\end{array}$ & 0.38 & $\begin{array}{l}1.15 \\
(0.97- \\
1.36)\end{array}$ & 0.089 & $\begin{array}{l}0.81 \\
(0.65- \\
1.02)\end{array}$ & 0.09 \\
\hline \multirow{2}{*}{$\begin{array}{l}\text { Maternal } \\
\text { occupation } \\
\text { status }\end{array}$} & Employed & Reference & ------- & Reference & ------- & Reference & ------- & Reference & ------- \\
\hline & Unemployed & $\begin{array}{l}1.11 \\
(1.00- \\
1.24)\end{array}$ & 0.036 & $\begin{array}{l}0.89 \\
(0.78- \\
1.01)\end{array}$ & 0.082 & $\begin{array}{l}0.92 \\
(0.82- \\
1.04)\end{array}$ & 0.223 & $\begin{array}{l}0.82 \\
(0.71- \\
0.95)\end{array}$ & 0.010 \\
\hline \multirow{2}{*}{$\begin{array}{l}\text { Paternal } \\
\text { occupation } \\
\text { status }\end{array}$} & Employed & Reference & ------- & Reference & ------- & Reference & ------- & Reference & ------- \\
\hline & Unemployed & $\begin{array}{l}1.00 \\
(0.89- \\
1.14)\end{array}$ & 0.881 & $\begin{array}{l}0.92(0.79- \\
1.08)\end{array}$ & 0.344 & $\begin{array}{l}0.89 \\
(0.77- \\
1.04)\end{array}$ & 0.151 & $\begin{array}{l}0.9(0.76- \\
1.09)\end{array}$ & 0.16 \\
\hline $\begin{array}{l}\text { Family } \\
\text { composition }\end{array}$ & Two parents & $\begin{array}{l}1.13 \\
(0.97- \\
1.31)\end{array}$ & 0.107 & $\begin{array}{l}1.39 \\
(1.13- \\
1.71)\end{array}$ & 0.002 & $\begin{array}{l}1.28 \\
(1.07- \\
1.54)\end{array}$ & 0.007 & $\begin{array}{l}0.94 \\
(0.75- \\
1.19)\end{array}$ & 0.649 \\
\hline
\end{tabular}




\begin{tabular}{|c|c|c|c|c|c|c|c|c|c|}
\hline & $\begin{array}{l}\text { Single } \\
\text { parent }\end{array}$ & Reference & -------- & Reference & -------- & Reference & -------- & Reference & -------- \\
\hline \multirow[t]{3}{*}{$\begin{array}{l}\text { Family } \\
\text { socioeconomic } \\
\text { status (SES) }\end{array}$} & low & $\begin{array}{l}1.22 \\
(1.12- \\
1.33)\end{array}$ & $<0.001$ & $\begin{array}{l}1.21 \\
(1.06- \\
1.38)\end{array}$ & 0.004 & $\begin{array}{l}1.12 \\
(1.01- \\
1.24)\end{array}$ & 0.021 & $\begin{array}{l}1.14 \\
(0.98- \\
1.33)\end{array}$ & 0.076 \\
\hline & mid & $\begin{array}{l}1.10 \\
(1.01- \\
1.20)\end{array}$ & 0.021 & $\begin{array}{l}1.10 \\
(1.00- \\
1.22)\end{array}$ & 0.050 & $\begin{array}{l}0.99 \\
(0.89- \\
1.10)\end{array}$ & 0.894 & $\begin{array}{l}1.02(0.91- \\
1.15)\end{array}$ & 0.644 \\
\hline & high & Reference & ------- & Reference & -------- & Reference & ------- & Reference & -------- \\
\hline
\end{tabular}




\begin{tabular}{|c|c|c|c|c|c|c|c|c|c|}
\hline \multirow[t]{3}{*}{ Variable } & & \multicolumn{4}{|c|}{ Life dissatisfaction } & \multicolumn{4}{|c|}{ Poor Self-rated health } \\
\hline & & \multicolumn{2}{|c|}{ Crude model } & \multicolumn{2}{|c|}{ Adjusted model* } & \multicolumn{2}{|c|}{ Crude model } & \multicolumn{2}{|c|}{ Adjusted model* } \\
\hline & & $\begin{array}{l}\text { OR }(95 \% \\
\text { CI) }\end{array}$ & $\begin{array}{l}P \text { - } \\
\text { value }\end{array}$ & $\begin{array}{l}\text { OR }(95 \% \\
\mathrm{CI})\end{array}$ & $\begin{array}{l}P \text { - } \\
\text { value }\end{array}$ & $\begin{array}{l}\text { OR }(95 \% \\
\text { CI) }\end{array}$ & $\begin{array}{l}P \text { - } \\
\text { value }\end{array}$ & $\begin{array}{l}\text { OR }(95 \% \\
\mathrm{CI})\end{array}$ & $\begin{array}{l}\text { P- } \\
\text { value }\end{array}$ \\
\hline \multirow[t]{2}{*}{ Sex } & Girl & Reference & ------- & Reference & ------- & Reference & -------- & Reference & ------- \\
\hline & Boy & $\begin{array}{l}0.99(0.92 \\
-1.07)\end{array}$ & 0.738 & $\begin{array}{l}1.00 \\
(0.92- \\
1.08)\end{array}$ & 0.940 & $\begin{array}{l}0.97 \\
(0.89- \\
1.05)\end{array}$ & 0.538 & $\begin{array}{l}0.97 \\
(0.89- \\
1.06)\end{array}$ & 0.535 \\
\hline \multirow[t]{2}{*}{ Living area } & Urban & Reference & ------- & Reference & ------- & Reference & ------- & Reference & ------- \\
\hline & Rural & $\begin{array}{l}1.06 \\
(0.97- \\
1.16)\end{array}$ & 0.213 & $\begin{array}{l}1.04 \\
(0.94- \\
1.15)\end{array}$ & 0.480 & $\begin{array}{l}0.97 \\
(0.88- \\
1.07)\end{array}$ & 0.589 & $\begin{array}{l}0.98 \\
(0.89- \\
1.08)\end{array}$ & 0.762 \\
\hline \multirow[t]{2}{*}{ Family size } & $\leq 4$ & Reference & -------- & Reference & ------- & Reference & ------- & Reference & -------- \\
\hline & $>4$ & $\begin{array}{l}1.30(1.21 \\
-1.41)\end{array}$ & $<0.001$ & $\begin{array}{l}1.14 \\
(1.03- \\
1.25)\end{array}$ & 0.011 & $\begin{array}{l}0.99 \\
(0.91- \\
1.08)\end{array}$ & 0.955 & $\begin{array}{l}0.98 \\
(0.89- \\
1.09)\end{array}$ & 0.826 \\
\hline \multirow{3}{*}{$\begin{array}{l}\text { Maternal } \\
\text { education } \\
\text { level }\end{array}$} & $\begin{array}{l}\text { College } \\
\text { degree }\end{array}$ & Reference & ------- & Reference & ------- & Reference & ------- & Reference & ------- \\
\hline & $\begin{array}{l}\text { Diploma and } \\
\text { less }\end{array}$ & $\begin{array}{l}1.02(0.89 \\
-1.18)\end{array}$ & 0.825 & $\begin{array}{l}1.12 \\
(0.93- \\
1.33)\end{array}$ & 0.237 & $\begin{array}{l}1.17 \\
(1.01- \\
1.35)\end{array}$ & 0.033 & $\begin{array}{l}1.26 \\
(1.04- \\
1.51)\end{array}$ & 0.015 \\
\hline & illiterate & $\begin{array}{l}1.59(1.35 \\
-1.85)\end{array}$ & $<0.001$ & $\begin{array}{l}1.64 \\
(1.30- \\
2.08)\end{array}$ & $<0.001$ & $\begin{array}{l}1.49 \\
(1.27- \\
1.76)\end{array}$ & $<0.001$ & $\begin{array}{l}1.60(1.25- \\
2.04)\end{array}$ & $<0.001$ \\
\hline \multirow{3}{*}{$\begin{array}{l}\text { Paternal } \\
\text { education } \\
\text { level }\end{array}$} & $\begin{array}{l}\text { College } \\
\text { degree }\end{array}$ & Reference & ------- & Reference & ------- & Reference & ------- & Reference & ------- \\
\hline & $\begin{array}{l}\text { Diploma and } \\
\text { less }\end{array}$ & $\begin{array}{l}1.12(0.99 \\
-1.27)\end{array}$ & 0.082 & $\begin{array}{l}1.07 \\
(0.94- \\
1.22)\end{array}$ & 0.28 & $\begin{array}{l}1.36 \\
(1.19- \\
1.56)\end{array}$ & $<0.001$ & $\begin{array}{l}1.28 \\
(1.09- \\
1.50)\end{array}$ & 0.002 \\
\hline & illiterate & $\begin{array}{l}1.19(1.01 \\
-1.39)\end{array}$ & 0.043 & $\begin{array}{l}1.05(0.88- \\
1.25)\end{array}$ & 0.66 & $\begin{array}{l}1.46 \\
(1.23- \\
1.73)\end{array}$ & $<0.001$ & $\begin{array}{l}1.28 \\
(1.03- \\
1.61)\end{array}$ & 0.03 \\
\hline \multirow{2}{*}{$\begin{array}{l}\text { Maternal } \\
\text { occupation } \\
\text { status }\end{array}$} & Employed & Reference & ------- & Reference & ------- & Reference & ------- & Reference & ------- \\
\hline & Unemployed & $\begin{array}{l}1.03(0.92 \\
-1.16)\end{array}$ & 0.661 & $\begin{array}{l}0.87 \\
(0.75-1.01 \\
)\end{array}$ & 0.060 & $\begin{array}{l}1.10 \\
(0.96- \\
1.25)\end{array}$ & 0.138 & $\begin{array}{l}0.91 \\
(0.78- \\
1.07)\end{array}$ & 0.275 \\
\hline \multirow{2}{*}{$\begin{array}{l}\text { Paternal } \\
\text { occupation } \\
\text { status }\end{array}$} & Employed & Reference & ------- & Reference & ------- & Reference & ------- & Reference & ------- \\
\hline & Unemployed & $\begin{array}{l}1.20(1.04 \\
-1.37)\end{array}$ & 0.011 & $\begin{array}{l}1.05 \\
(0.88- \\
1.25)\end{array}$ & 0.578 & $\begin{array}{l}1.26 \\
(1.07- \\
1.47)\end{array}$ & 0.005 & $\begin{array}{l}1.58 \\
(1.29- \\
1.81)\end{array}$ & $<0.001$ \\
\hline $\begin{array}{l}\text { Family } \\
\text { composition }\end{array}$ & Two -parent & $\begin{array}{l}0.81 \\
(0.69- \\
0.94)\end{array}$ & 0.007 & $\begin{array}{l}0.76 \\
(0.61- \\
0.95)\end{array}$ & 0.014 & $\begin{array}{l}0.95 \\
(0.79- \\
1.13)\end{array}$ & 0.579 & $\begin{array}{l}0.87 \\
(0.68- \\
1.11)\end{array}$ & 0.276 \\
\hline
\end{tabular}




\begin{tabular}{|c|c|c|c|c|c|c|c|c|c|}
\hline & $\begin{array}{l}\text { Single - } \\
\text { parent }\end{array}$ & Reference & -------- & Reference & -------- & Reference & -------- & Reference & -------- \\
\hline \multirow[t]{3}{*}{$\begin{array}{l}\text { Family } \\
\text { socioeconomic } \\
\text { status (SES) }\end{array}$} & low & $\begin{array}{l}1.47 \\
(1.39- \\
1.61)\end{array}$ & $<0.001$ & $\begin{array}{l}1.35 \\
(1.15- \\
1.56)\end{array}$ & $<0.001$ & $\begin{array}{l}1.14 \\
(1.03- \\
1.27)\end{array}$ & 0.012 & $\begin{array}{l}0.95 \\
(0.81- \\
1.12)\end{array}$ & 0.567 \\
\hline & mid & $\begin{array}{l}1.03 \\
(0.92- \\
1.15)\end{array}$ & 0.622 & $\begin{array}{l}1.06 \\
(0.94- \\
1.21)\end{array}$ & 0.331 & $\begin{array}{l}1.04 \\
(0.94- \\
1.16)\end{array}$ & 0.403 & $\begin{array}{l}0.95 \\
(0.84- \\
1.08)\end{array}$ & 0.483 \\
\hline & high & Reference & -------- & Reference & -------- & Reference & -------- & Reference & ------- \\
\hline
\end{tabular}

*In the adjusted model, all socioeconomic status variables and age are simultaneously in the model 